\title{
Potential Involvement of a Cucumber Homolog of Phloem Protein 1 in the Long-Distance Movement of Cucumber mosaic virus Particles
}

\author{
A. Requena, L. Simón-Buela, G. Salcedo, and F. García-Arenal \\ Dpto. Biotecnología, ETSI. Agrónomos, Universidad Politécnica de Madrid, Avda. Complutense s/n, 28040 Madrid, Spain
}

Submitted 31 January 2006. Accepted 28 February 2006.

\begin{abstract}
The systemic movement of Cucumber mosaic virus (CMV) in cucumber plants was analyzed. The structure that is translocated and its putative interactions with phloem components were analyzed in phloem exudate (PE) samples, which reflect sieve tubes stream composition. Rate zonal centrifugation and electron-microscopy analyses of PE from CMV-infected plants showed that CMV moves through sieve tubes as virus particles. Gel overlay assays revealed that $\mathrm{CMV}$ particles interact with a $\mathrm{PE}$ protein, p48. The amino-acid sequence of several tryptic peptides of p48 was determined. Partial amino-acid sequence of p48 showed it was a cucumber homolog of phloem protein 1 (PP1) from pumpkin, with which p48 also shares several chemical properties. PP1 from pumpkin has plasmodesmata-gating ability and translocates in sieve tubes. Encapsidated CMV RNA in PE samples from infected plants was less accessible to digestion by RNase A than RNA in purified CMV particles, a property that was reconstituted by the in vitro interaction of purified CMV particles and protein $\mathbf{p 4 8}$. These results indicate that the interaction with p48 modifies CMV particle structure and suggest that CMV particles interact with the cucumber homolog of PP1 during translocation in the sieve tubes.
\end{abstract}

Additional keywords: phloem proteins, phloem transport.

It has been shown in the recent past that, in addition to its role in the transport of photoassimilates and other nutrients, the phloem has a function as an information pathway for interorgan communication, in which macromolecules, including RNA, traffic long distance. At least three types of RNA are transported through the phloem, endogenous mRNAs, small RNAs involved in gene silencing, and exogenous RNAs of plant pathogens (Lucas 2006; Oparka and Santa Cruz 2000; Ruíz-Medrano et al. 2001; Scholthof 2005; Thompson and Schulz 1999). Similarities and differences may occur in the transport of endogenous and pathogenic RNAs. Pathogenic RNAs must pass several cell borders to access the sieve element (SE), while endogenous RNAs may be synthesized in the companion cells. Little is known on the mechanisms of transport once RNAs enter sieve tubes, but a common feature may be the transport of RNAs in ribonucleoprotein (RNP) struc-

Corresponding author: F. García-Arenal: Telephone: +91 33657 68; Fax: +91 33657 57; E-mail: fernando.garciaarenal@upm.es

Current address for L. Simón-Buela: Progenika. Parque Tecnológico de Zamudio. Edificio 801-A 48160. Derio-Spain. tures (Gómez et al. 2005). Transport of pathogenic RNAs in the phloem of host plants reveals adaptation to endogenous macromolecular trafficking. Hence, the analysis of systemic movement of plant viruses may highlight the mechanisms for both endogenous and pathogenic RNA trafficking (Boevink and Oparka 2005; Lucas 2006; Scholthof 2005; Thompson and Schulz 1999).

Plant viruses are systemic pathogens that infect a susceptible host in a multiple-step process. First, the virus replicates in the initially infected cells and moves to surrounding cells through the plasmodesmata. Through this cell-to-cell movement, viruses colonize the parenchymatic tissues of one or more infected organs reaching the veins, from which systemic or long-distance movement occurs through the phloem for most viruses, following the photoassimilate path from source to sink organs. Thus, viruses must enter the vascular system, access, move through, and exit from sieve tubes, exit the vascular system, and infect nonvascular cells of sink tissues. Any of these steps may be blocked in plants that are resistant to systemic colonization by viruses. Comparisons of systemic infection of two unrelated viruses in the same host and analyses of mutant viruses impaired for long-distance movement show that compatible interactions between host and virus factors are required for systemic movement (Nelson and van Bel 1998; Oparka and Santa Cruz 2000; Thompson and Schulz 1999; Waigmann et al. 2004).

Little is known about how viruses access and move into sieve elements (SE), and different mechanisms have been postulated. Viruses could move as virions or as RNP structures through plasmodesmata or through virus-induced tubules into the SE, in which these structures would be carried by the phloem translocation stream. Alternatively, assembly of moving structures could take place at SE prior to long-distance movement (Oparka and Santa Cruz 2000). Knowledge on the translocated viral structure is limited, but different evidence suggests it is the virion. Electron microscopy observations of virus particles at SE in different host-virus systems (Oparka and Turgeon 1999; Santa Cruz 1999; Thompson and Schulz 1999) would support this hypothesis. However, electron microscopy observation of fixed samples does not determine whether virions were found in SE due to accumulation at some time during the infection process or whether they were translocating through sieve tubes (Nelson and van Bel 1998). Many viruses need a functional capsid protein $(\mathrm{CP})$ to move systemically, and CP mutants defective for both encapsidation and systemic movement have been reported (Ding et al. 1996; Vaewhongs and Lommel 1995; Xiong et al. 1993). However, encapsidation and movement may be uncoupled, as shown by CP mutants of Carnation ring spot virus (genus Dianthovirus) that form virus 
particles but do not move (Sit et al. 2001). Analyses of the phloem translocation stream provided direct evidence that $\mathrm{Cu}$ cumber green mottle mosaic virus (CGMMV) (genus Tobamovirus) moves through the phloem of cucumber (Cucumis sativus L.) plants as virus particles (Simón-Buela and García-Arenal 1999).

In this work, we examine different aspects of the systemic movement of Cucumber mosaic virus (CMV) in cucumber plants to illustrate phloem translocation of pathogenic RNAs. CMV is the type member of the genus Cucumovirus and needs both the movement protein (MP) and the CP for cell-to-cell and systemic movement (Suzuki et al. 1991). MP has strainspecific determinants for long-distance movement, as shown by analyses in squash (Cucurbita pepo L.) of strains competent or defective for systemic movement (Kaplan et al. 1997). CMV CP is also needed for systemic movement and has also host-specific determinants for this function. Microscopy analysis of the progress of infection of the viruses defective for systemic movement showed accumulation in the bundle sheath cells, indicating that specific interactions between CMV CP and host factors are necessary to access the vascular system and move systemically (Ryabov et al. 1999; Taliansky and GarcíaArenal 1995; Thompson and García-Arenal 1998). CMV also needs a CP able to form viral particles to move systemically, as shown by N-terminal CP mutants that do not form virus particles (Kaplan et al. 1998; Schmitz and Rao 1998), and CMV particles in membrane-bound structures have been observed in SE of Nicotiana clevelandii Gray (Blackman et al. 1998). Direct evidence from the phloem translocation stream to confirm that CMV moves long distance as virus particles is lacking, as is information on interaction with host factors during CMV movement in the sieve tubes.

Here, we report on analyses of phloem exudates (PE) samples from CMV-infected cucumber plants aimed at characterizing the CMV form that moves systemically and at identifying host factors that interact with it. It is shown that translocation occurs as virus particles and that the properties of these particles are modified by the interaction with a phloem protein homologous to phloem protein 1 (PP1) described in other cucurbits.

\section{RESULTS}

\section{Characterization of one or more viral structures present in the PE of CMV-infected cucumber plants.}

When PE samples from CMV-infected cucumber plants were used to inoculate fully expanded leaves of Chenopodium quinoa Willd., local lesions similar in size and form to those induced by purified CMV particles developed in the same period (5 days postinoculation, dpi) (data not shown), indicating the presence of one or more infectious forms of CMV in the PE samples. The presence of CMV RNA and CP in the PE from infected plants was analyzed by dot-blot hybridization and by Western blot, respectively, in samples taken 2, 4, 6, 8, 10, 12, and 14 dpi. Both CMV RNA and CP were detected from 4 dpi onwards, with similar maxima between 4 and 8 dpi (data not shown). For subsequent experiments, samples were taken between 6 and 8 dpi.

To characterize whether or not the RNA and CP of CMV in the PE of infected plants were associated with RNP structures, their sedimentation profiles were compared with those of RNA and $\mathrm{CP}$ in CMV particles purified from infected leaves. For this, PE from CMV-infected cucumber plants and purified CMV particles, alone or mixed with PE from noninoculated cucumber plants, were centrifuged in 5 to $25 \%$ sucrose gradients, and the sedimentation profiles of CMV RNA and CP were compared. Figure 1A shows the RNA sedimentation profiles of one representative assay of six independent ones. RNA
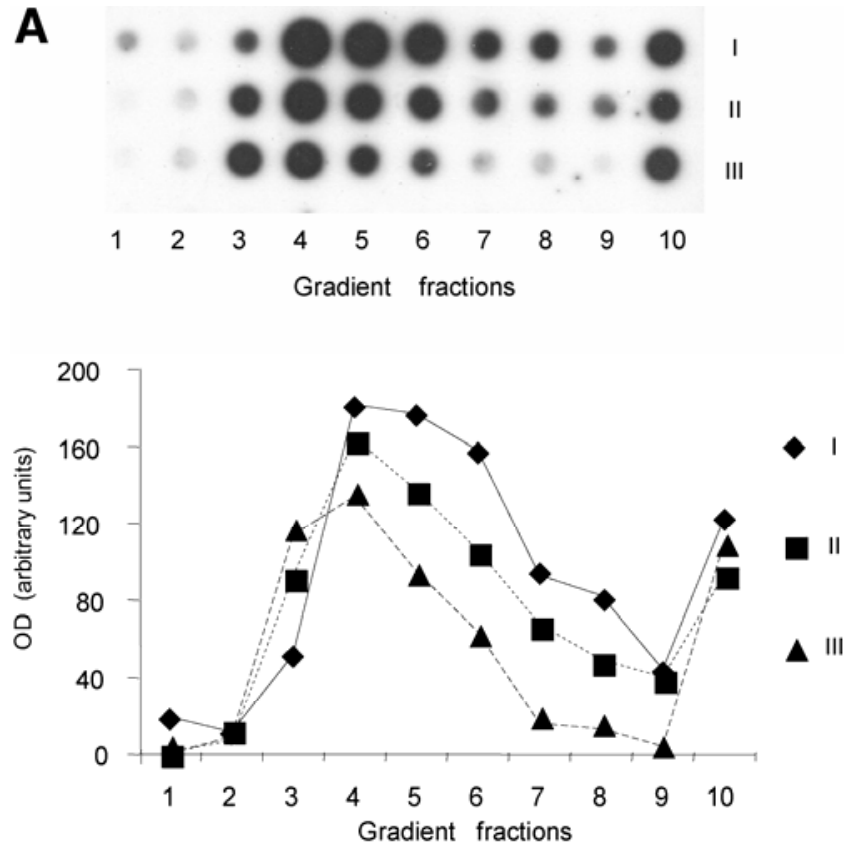

B
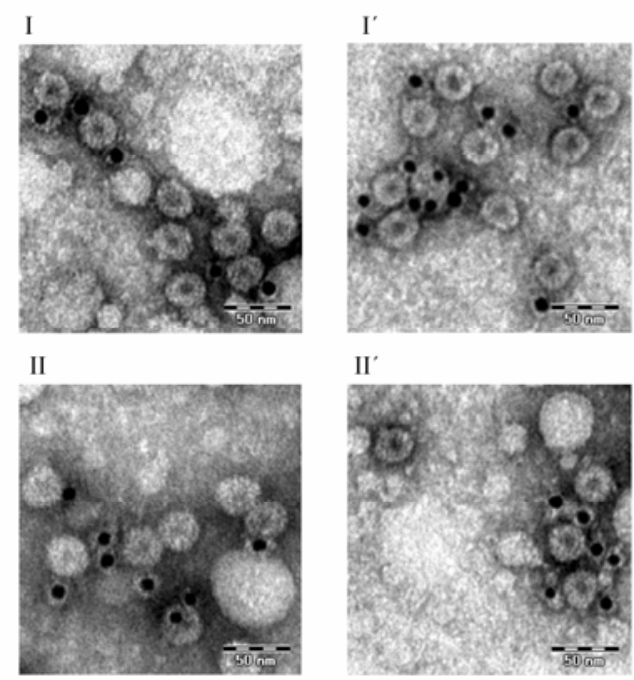

III

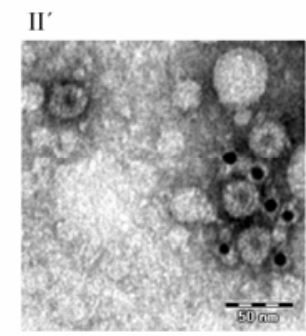

III'
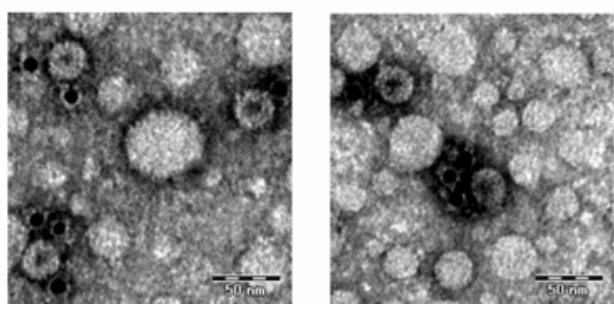

Fig. 1. Analysis of one or more Cucumber mosaic virus (CMV) structures present in phloem exudate (PE) of CMV-infected cucumber plants. A, Sedimentation profiles of CMV-related structures present in PE from CMV-infected cucumber plants. Purified virus particles, alone (I, $>)$ or mixed with PE from noninoculated cucumber plants (II, $\mathbf{0})$ and PE from CMV-infected cucumber plants (III, $\boldsymbol{\Delta}$ ), were centrifuged in 5 to $25 \%$ sucrose gradients, which were fractionated from top (1) to bottom (10). CMV RNA was detected by dot-blot hybridization with a probe complementary to nucleotides 1,257 to 1,912 of CMV RNA 3. Densitometric profiles are shown as a graph at the bottom of the panel. Optical density (OD) values in arbitrary units are on the $y$ axis. B, Electron micrographs of fractions 4 to $6(\mathrm{I})$ and $10\left(\mathrm{I}^{\prime}\right)$ from sucrose gradients loaded with purified virus particles, of fractions 3 to 5 (II) and 10 (II') from gradients loaded with purified virus particles mixed with PE from noninoculated cucumber plants, or with PE from CMV-infected cucumber plants (III and III'). $^{\prime}$. 
from purified virus particles sedimented into two peaks, in fractions 4 to 6 and in 10 (Fig. 1A, I). RNA from purified virus particles mixed with $\mathrm{PE}$ of noninoculated cucumber plants or from PE of CMV-infected cucumber plants sedimented also into two peaks, the first one in fractions 3 to 5 and the second one in fraction 10 (Fig. 1A, II and III). In all cases, sedimentation profiles of the $\mathrm{CP}$ were as for CMV RNA (data not shown). Cosedimentation of CMV RNA and CP present in the $\mathrm{PE}$ of infected cucumber plants, with a profile similar to that of purified particles mixed with PE of noninoculated cucumber plants, suggests that CMV RNA and $\mathrm{CP}$ are associated into virions in the PE of infected plants.

Sucrose gradients fractions enriched in CMV RNA and CP were pelleted and nickel grids were floated over the resus- pended pellets. Grids were incubated with CMV antiserum and with goat anti-rabbit antibodies conjugated to gold particles before negative staining for electron microscopy. Gold-marked CMV isometric particles., with a diameter of $30 \mathrm{~nm}$ and an electron-dense core (Habili and Francki 1974a) were observed in fractions 4 to 6 and 10 from gradients loaded with purified virus particles (Fig. 1B, I and $\mathrm{I}^{\prime}$ ) and in fractions 3 to 5 and 10 from gradients loaded with virus particles mixed with $\mathrm{PE}$ from noninoculated cucumber plants (Fig. 1B, II and II') or with PE from CMV-infected cucumber plants (Fig.1B, III and III'). Gold particles were seen only in association with CMV particles. The same structures and no others were observed in the second sedimentation peak (fraction 10) of the gradients, indicating that this peak corresponded to aggregated particles. These

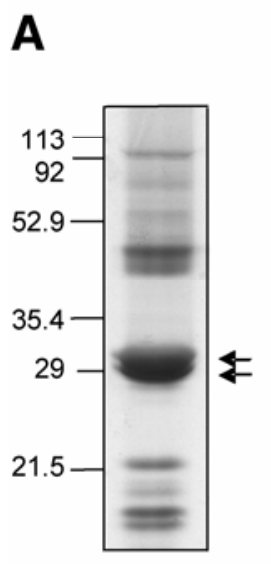

B
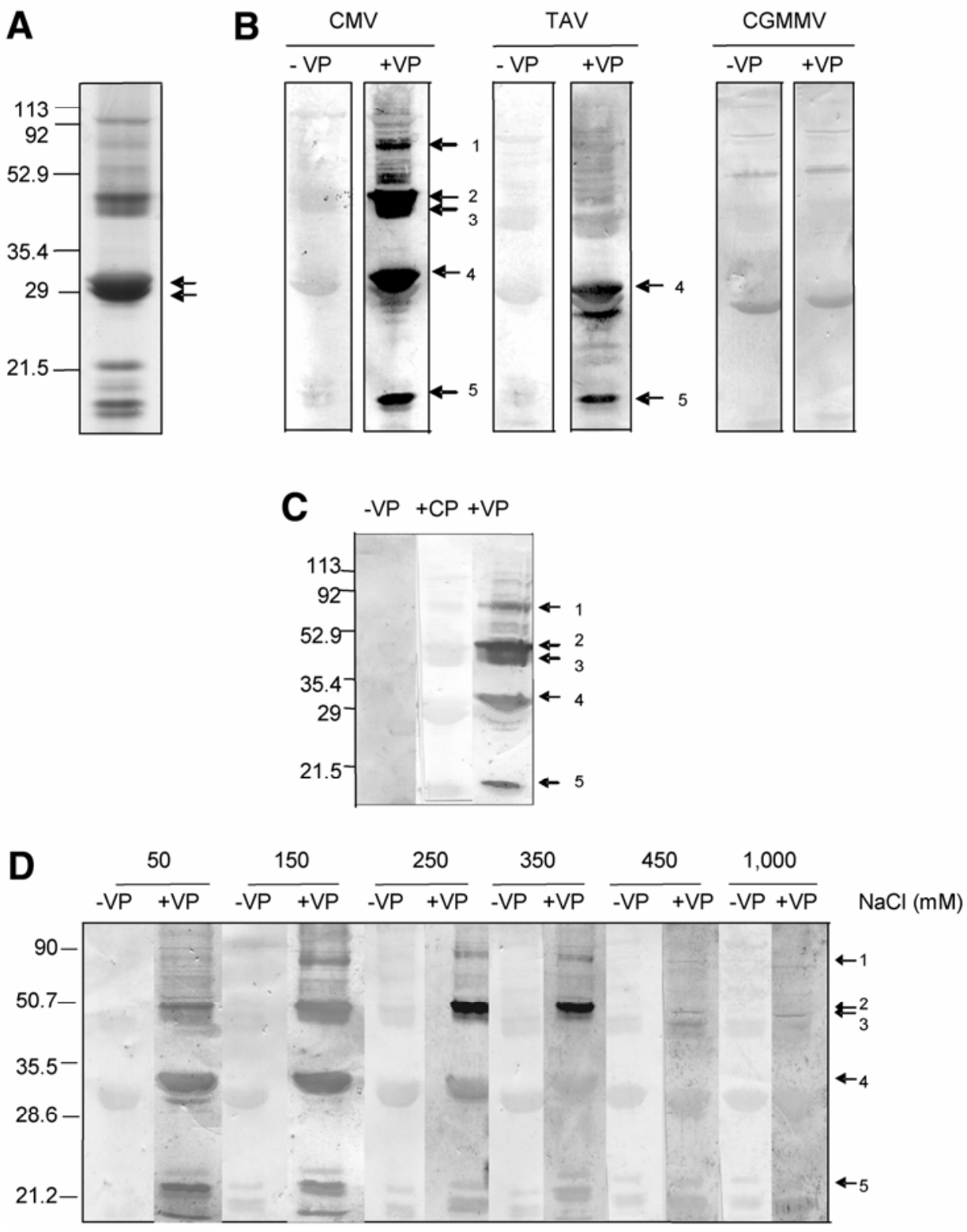

Fig. 2. Interactions between phloem exudate (PE) proteins and Cucumber mosaic virus (CMV) particles shown by overlay assays. A, Proteins (20 $\mu \mathrm{g})$ from $\mathrm{PE}$ of noninoculated cucumber plants were fractionated by sodium dodecyl sulfate-polyacrylamide gel electrophoresis and were stained with Coomassie brilliant blue. Arrows indicate the position of the two monomers of phloem protein 2 (molecular weights 32 and $30 \mathrm{kDa}$, respectively). B, C, and D, Gel overlay assays. Interactions were detected by incubating the membranes with sera against the respective virus. Arrows 1 through 5 indicate the position of CMV and Tomato aspermy virus (TAV) interacting proteins. B, Membranes were incubated in renaturation buffer alone (-VP) or with $20 \mu \mathrm{g}$ of virus particles per milliliter (+VP) of CMV, TAV, and Cucumber green mottle mosaic virus (CGMMV), as indicated. C, Membranes were incubated in renaturation buffer alone (-VP), with $20 \mu \mathrm{g}$ of CMV capsid protein per milliliter (+CP), and with $20 \mu \mathrm{g}$ of CMV particles per milliliter (+VP). D, Membranes were incubated with renaturation buffer with increasing $\mathrm{NaCl}$ concentrations as indicated, alone $(-\mathrm{VP})$, or with CMV particles at $20 \mu \mathrm{g} / \mathrm{ml}(+\mathrm{VP})$. Molecular mass standards $(\mathrm{kDa})$ are indicated at the left of the panels. 
results show the presence of CMV particles in PE from CMVinfected cucumber plants. No other CMV-related structure was detected with these experimental approaches.

\section{Characterization of interactions between proteins of PE from cucumber plants and CMV particles.}

Putative interactions between CMV particles and PE proteins were analyzed by a virus overlay assay in which PE proteins, electro-transferred to polyvinylidene diflouride (PVDF) membranes after sodium dodecyl sulfate-polyacrylamide gel electrophoresis (SDS-PAGE), were probed with CMV particles (discussed below). Figure 2A shows the protein profile of the $\mathrm{PE}$ of noninoculated cucumber plants as a reference. Figure 2B (CMV, -VP lane), shows that the CMV antiserum reacted weakly and unspecifically with some PE proteins, mostly with abundant ones like monomers of PP2. Figure 2B also shows that the CMV antiserum detected several PE proteins in membranes incubated with CMV particles, indicating the interaction between CMV particles and PE proteins with apparent molecular weights of 69, 48, 44, 32, and $18 \mathrm{kDa}$ (Fig. 2B, $\mathrm{CMV},+\mathrm{VP}$ lane, arrows 1 to 5), herein designated as $\mathrm{p} 69$, p48, p44, p32, and p18.

To analyze whether these interactions were specific to CMV particles, virus overlay assays were carried out with particles of Tomato aspermy virus (TAV) or CGMMV. CGMMV antiserum weakly detected the same PE proteins in membranes incubated with or without CGMMV particles (Fig. 2B, CGMMV, lanes $-\mathrm{VP}$ and $+\mathrm{VP})$. TAV antiserum reacted weakly and nonspecifically with the most abundant PE proteins (Fig. 2B, TAV, lane -VP) and detected two PE proteins in membranes incubated with TAV particles, p32 and p18 (Fig. 2B, TAV, lane $+\mathrm{VP}$, arrows 4 and 5) that also interacted with CMV particles. Together, these results indicated the specificity of the interaction of CMV particles with proteins p69, p48, and p44 of the $\mathrm{PE}$ of cucumber plants but not with proteins $\mathrm{p} 32$ and $\mathrm{p} 18$.

It was also analyzed to determine whether proteins p69, p48, and p44 interacted with soluble CMV CP, obtained by disrupting purified CMV particles with $\mathrm{LiCl}$ (Kaper 1969). CMV antiserum did not detect $\mathrm{PE}$ proteins in the membranes incubated with $\mathrm{CMV} \mathrm{CP}$ (Fig. $2 \mathrm{C}$, lane $+\mathrm{CP}$ ), indicating that proteins p69, p48, p44, p32, and p18 interact with CMV particles but not with CMV CP monomers.

The affinity of the interaction between proteins p69, p48, and p44 and CMV particles was analyzed in gel overlay assays in which membranes were incubated with CMV particles in renaturation buffer with increasing $\mathrm{NaCl}$ concentrations. Figure 2D shows that CMV particles interacted with protein p69, p48 and p44 up to $350 \mathrm{mM} \mathrm{NaCl}$, whereas interactions with p32 and p18 was disrupted at lower $\mathrm{NaCl}$ concentrations (maximum $250 \mathrm{mM}$ ) (Fig. 2D, +VP lanes). CMV particles did not interact with $\mathrm{PE}$ proteins at 450 or $1,000 \mathrm{mM} \mathrm{NaCl}$. The lack of interactions between CMV particles and PE proteins at 450 $\mathrm{mM} \mathrm{NaCl}$ was not due to particle disruption, as $\mathrm{CMV}$ particles were stable at this $\mathrm{NaCl}$ concentration but were disrupted at $1,000 \mathrm{mM} \mathrm{NaCl}$ (data not shown), in agreement with previous reports (Kaper 1969). Hence, these results showed that the stability of the interaction between PE proteins and CMV particles was highest for proteins p69, p48, and p44.

The most abundant of these proteins (p48) was purified for further characterization. Proteins in the PE from cucumber plants were initially fractionated by size exclusion chromatography, and fractions enriched in protein $\mathrm{p} 48$ were pooled and further fractionated by cation exchange chromatography. Fractions enriched in p48 were again pooled (fraction P48), in which protein p44 was also present (Fig. 3A, P48 lane). Gel overlay assays showed that both proteins in fraction $\mathrm{P} 48$ interacted with CMV particles as for PE (Fig. 3B, +VP).

\section{Proteins p48 and p44 protect CMV-encapsidated RNA against RNase $A$.}

To assess whether interactions between CMV particles and PE proteins could modify the properties of CMV particles, the sensitivity to RNase A of encapsidated CMV RNA was assayed in crude PE samples from noninoculated cucumber plants as well as in PE fractionated into a protein fraction and a lowmolecular weight nonprotein fraction. Ions and low-molecular weight compounds were removed from whole PE samples by dialysis against water, and proteins were eliminated by phenol extraction. Purified CMV particles mixed with buffer (PEB), with dialyzed PE, with phenol-extracted PE, or with whole PE were incubated with RNase A, and nondigested RNA was amplified by reverse transcription-polymerase chain reaction (RTPCR) after phenol extraction. The expected PCR product was only detected when CMV particles mixed with PEB were incubated with the lowest RNase A concentration assayed $\left(2 \times 10^{-4}\right.$ $\mu \mathrm{g} / \mu \mathrm{l}$; Fig. 4A, PEB). The expected PCR product was detected at higher RNase A concentrations when CMV particles were mixed with PE, whether it was dialyzed or not $\left(2.5 \times 10^{-2}\right.$ to $2 \times$ $10^{-4} \mu \mathrm{g} / \mu \mathrm{l}$; Fig. 4A, PE-dialyzed and PE) but not when CMV particles were mixed with phenol-extracted PE (Fig. 4A, PEphenol). These results indicate that the RNA within purified CMV particles mixed with PE was less accessible to RNase A digestion than RNA within purified CMV particles, an effect probably due to interaction with proteins in the PE sample. PE proteins could hinder the accessibility of encapsidated CMV RNA to RNAse A, inhibit the activity of RNAse A, or both.

Incubation of RNase A with PE prior to RNA digestion did not inhibit enzymatic activity as shown in Figure 4B. RNase A activity towards CGMMV RNA was not affected by incubation with PE, irrespective of incubation time (Fig. 4B, 5 and 30 min). Furthermore, Figure 4C uncovered ribonuclease activity in $\mathrm{PE}$, as shown by the progressive degradation of CGMMV RNA when incubated with PE for 0,5 , or $30 \mathrm{~min}$. Hence, the lower sensitivity to RNase A of CMV RNA in purified virions mixed with PE is not due to RNase A inhibition but to a diminished accessibility of the encapsidated RNA to RNase A by interaction with PE proteins.

Considering these results, the effect of proteins p48 and p44 on the accessibility of encapsidated CMV RNA to RNase A was then analyzed. Figure 4D shows that sensitivity to RNase A of the RNA in purified virus particles mixed with the P48 fraction is lower than that of RNA in purified virus particles mixed with PEB and similar to that of RNA in purified virus

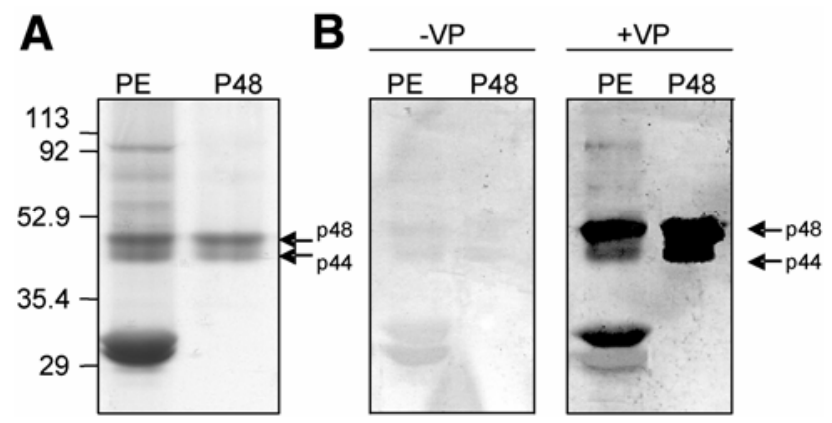

Fig. 3. Purification of proteins $\mathrm{p} 48$ and p44 from phloem exudate (PE) from cucumber plants. A and $\mathbf{B}$, Proteins $(20 \mu \mathrm{g})$ from PE of noninoculated cucumber plants (PE) and fraction P48 $(5 \mu \mathrm{g})$ were fractionated by sodium dodecyl sulfate-polyacrylamide gel electrophoresis. A, Coomassie brilliant blue staining. B, Gel overlay assay. Membranes were incubated in renaturation buffer alone (-VP) or with $20 \mu \mathrm{g}$ of Cucumber mosaic virus $(\mathrm{CMV})$ particles per milliliter $(+\mathrm{VP})$. Interactions were detected incubating membranes with CMV antiserum. The position of proteins p48 and p44 is indicated. Numbers at the left of the panels indicate molecular mass standards in $\mathrm{kDa}$. 
particles mixed with PE. This indicates that interactions with proteins $\mathrm{p} 48$ and $\mathrm{p} 44$ are responsible, at least in part, for the decreased sensitivity to RNase A of encapsidated CMV RNA mixed with $P E$ of noninoculated plants.

Finally, sensitivity to RNase A of RNA in CMV particles of PE from infected cucumber plants was compared with that of RNA within purified virus particles. Sensitivity to RNase A of RNA in CMV particles of PE from infected plants (Fig. 4E, PE-CMV) was lower than that of RNA in purified virus particles (Fig. 4E, CMV VP + PEB) and similar to that of RNA in purified virus particles mixed with $\mathrm{PE}$ from noninoculated plants (Fig. 4E, CMV VP + PE). Observed differences in RTPCR amplification after RNase A digestion of virion RNA from CMV particles mixed with $\mathrm{PE}$ from noninoculated plants and from PE of infected plants could be due to fewer virus particles in the PE from infected plants. This result, together with those described above, suggests that CMV particles that move through cucumber sieve tubes interact with phloem proteins p48 and $\mathrm{p} 44$.

\section{Characterization of proteins p48 and p44 of PE from cucumber plants.}

Proteins in the P48 fraction of PE proteins (Fig. 3A) were separated by two-dimensional (2-D) electrophoresis. Isoelectric focusing (IEF) in a 6 to 11 linear $\mathrm{pH}$ gradient, and separation by mass in $8 \%$ SDS-PAGE resolved two clear spots with isoelectric points (pI) of 9.0 (p48) and 8.6 (p44) (Fig. 5A). The identity of these two spots as p48 and p44 was confirmed by their interaction with CMV particles in overlay assays (not shown).

Because phloem proteins, such as PP2 (Wang et al. 1994), can be glycosylated, the potential presence of complex asparagine-linked glycans in p48 and p44 was investigated using a rabbit antiserum against plant $\mathrm{N}$-linked complex glycans (García-Casado et al. 1996). No band was recognized by the antiserum in the P48 fraction, while a strong reaction was shown by horseradish peroxidase assayed as a positive control (Fig. 5B). Furthermore, the cross-link of PP2 and PP1 with each other and with other phloem proteins (Oparka and Turgeon

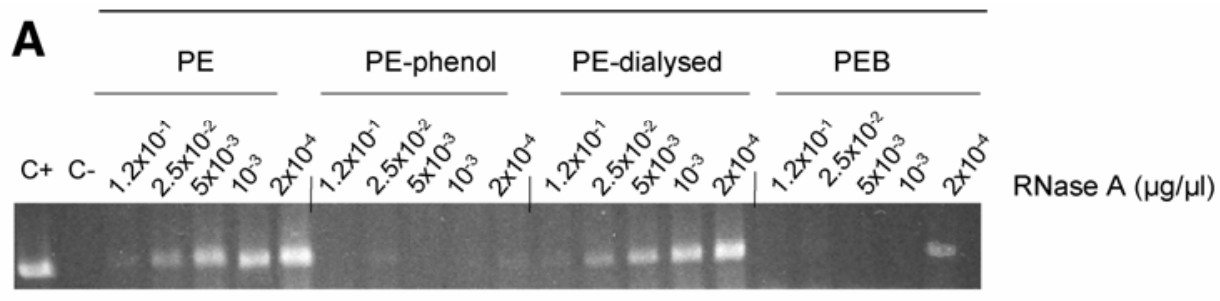

B CGMMV RNA + PE-incubated RNase A
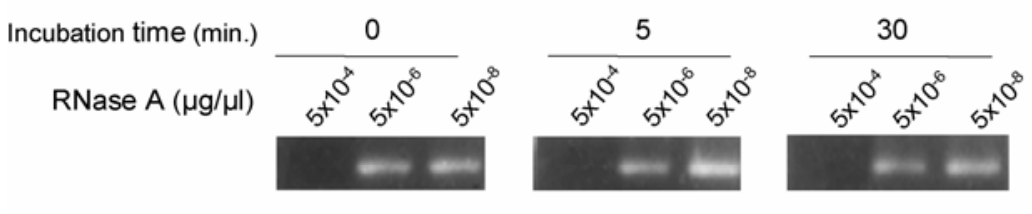

C CGMMV RNA+PE
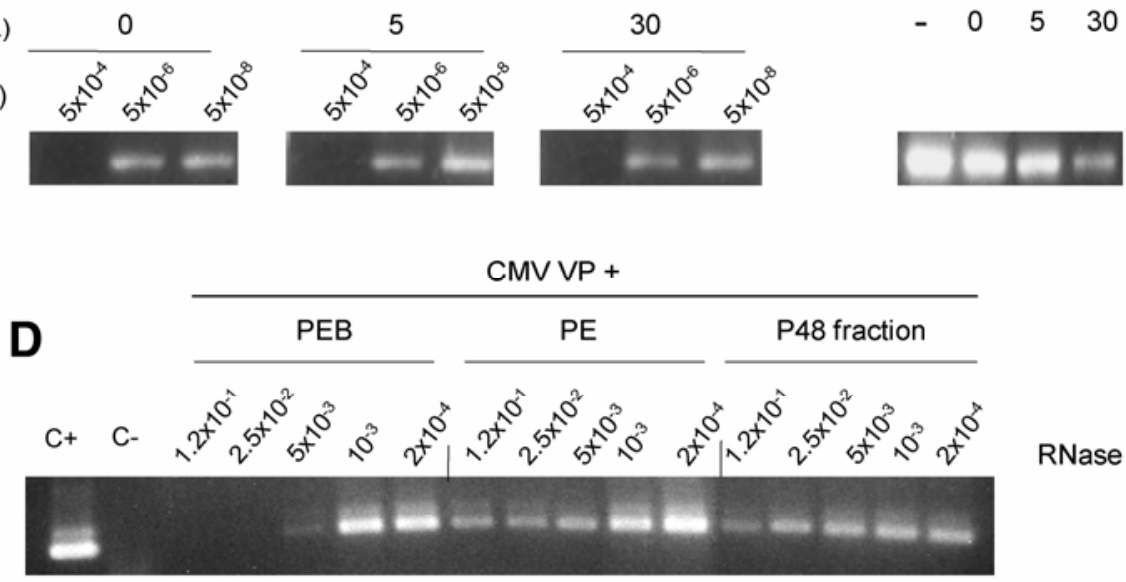

RNase $\mathrm{A}(\mu \mathrm{g} / \mu \mathrm{l})$

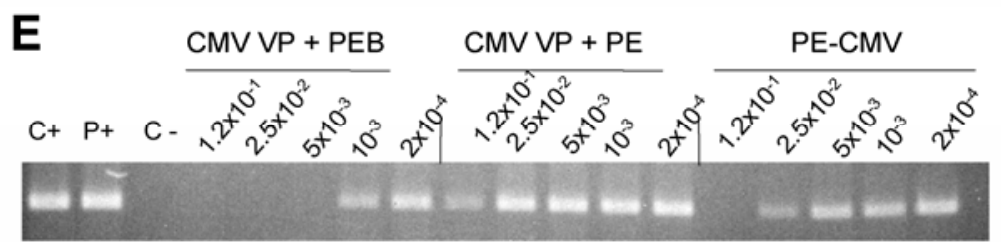

RNase A $(\mu g / \mu l)$

Fig. 4. Sensitivity of encapsidated Cucumber mosaic virus (CMV) RNA to RNase A digestion. A, CMV particles (200 ng, CMV +VP) mixed with phloem exudate (PE) from noninoculated cucumber plants (PE), with phenol-extracted PE (PE-phenol), with dialyzed PE (PE-dialysed), or with buffer (PEB) were digested with RNase A $\left(1.2 \times 10^{-1}\right.$ to $\left.2 \times 10^{-4} \mu \mathrm{g} / \mu \mathrm{l}\right)$ for $1 \mathrm{~h}$ at $37^{\circ} \mathrm{C}$. B, RNase A (final concentrations of $5 \times 10^{-4}, 5 \times 10^{-6}$, and $\left.5 \times 10^{-8} \mu \mathrm{g} / \mu \mathrm{l}\right) \mathrm{was}$ incubated with PE from cucumber plants for 0,5 , or $30 \mathrm{~min}$, and then, Cucumber green mottle mosaic virus (CGMMV) RNA (7.5 ng) was added and digested for $1 \mathrm{~h}$ at $37^{\circ} \mathrm{C}$. C, CGMMV RNA $(7.5 \mathrm{ng})$ was incubated at $37^{\circ} \mathrm{C}$ without (-) or with PE from cucumber plants for 0,5 , or $30 \mathrm{~min} . \mathrm{D}$, CMV particles (200 ng, $\mathrm{CMV}+\mathrm{VP}$ ), mixed with buffer (PEB), with PE from noninoculated cucumber plants (PE), or with fraction P48 (p48 fraction) were digested with RNase A $\left(1.2 \times 10^{-1}\right.$ to $\left.2 \times 10^{-4} \mu \mathrm{g} / \mu \mathrm{l}\right)$ for $1 \mathrm{~h}$ at $37^{\circ} \mathrm{C}$. E, CMV (200 $\mathrm{ng}$ ) mixed with buffer (CMV PV+PEB) or mixed with PE from noninoculated cucumber plants (CMV PV+PE) and PE from CMV-infected cucumber plants (PE-CMV) were digested with RNase A $\left(1.2 \times 10^{-1}\right.$ to $\left.2 \times 10^{-4} \mu \mathrm{g} / \mu \mathrm{l}\right)$ for $1 \mathrm{~h}$ at $37^{\circ} \mathrm{C}$. P+, phenol extracted PE from CMV-infected cucumber plants. In A, D, and E, after phenol extraction, nondigested CMV RNA 3 between nucleotides 1,250 and 1,925 was amplified by reverse transcription-polymerase chain reaction (RT-PCR), and amplicons were analyzed by agarose gel electrophoresis. C+, RTPCR positive control (CMV RNA phenol-extracted from purified particles); C-, RT-PCR negative control (water). In B and C, after phenol extraction, nondigested CGMMV RNA between nucleotides 4,321 and 4,680 was amplified by RT-PCR, and amplicons were analyzed by agarose gel electrophoresis. 
1999; Thompson and Schulz 1999) in nonreducing conditions prompted us to check the possible aggregation of p48 and p44 proteins in the absence of reducing agents ( $\beta$-mercapto-ethanol; Fig. 5C). Samples of PE from noninoculated cucumber plants and dialyzed P48 fraction were separated by SDS-PAGE, and virus overlay assays were done to identify CMV-interacting proteins. Whereas the CMV antiserum detected p48 in PE and P48 samples incubated in reducing conditions, in the absence of $\beta$-mercapto-ethanol, the antiserum detected an additional protein band of an apparent molecular weight of $95 \mathrm{kDa}$ (hereafter p95) in the P48 fraction. p95 was not highlighted by CMV antiserum in PE samples in nonreducing conditions, probably because of the interaction of p48 and p44 and other PE proteins forming aggregates that could not be resolved in the SDS-PAGE gel. p95 was the major CMV-interacting component in the $\mathrm{P} 48$ fraction under nonreducing conditions and could represent a p48 and p44 homo- or heterodimer stabilized by disulfide bridges, according to its apparent molecular size.

To further characterize p48 and p44 proteins, fraction P48 was analyzed by matrix-assisted laser desorption-ionization time of flight mass spectrometry (MALDI-TOF MS). The obtained spectrum had three major peaks, at 23,809.66, 47,297.70, and 94,485.40 $\mathrm{Da}$ (not shown). The 47.2 $\mathrm{kDa}$ peak fits well with the apparent molecular weight of protein $\mathrm{p} 48$, and the $94.4 \mathrm{kDa}$ peak with the p95 mentioned above (Fig. 5C). The 23.8-kDa peak represents the doubly charged species (i.e., doubly protonated during MALDI-TOF-MS) of the $47.2 \mathrm{kDa}$ peak. Interestingly, no peak at $44 \mathrm{kDa}$ was detected. MALDITOF MS analysis suggests that, in fraction P48, there are not two different proteins with molecular weights of 44 and 48 $\mathrm{kDa}$ but probably variants of a single $47.2 \mathrm{kDa}$ protein (protein $\mathrm{p} 48)$.
To identify p48, mass fingerprint profiles and partial protein sequences were also obtained. Mass fingerprint profiles were determined after separation of fraction $\mathrm{P} 48$ proteins by IEF in nonlinear $\mathrm{pH}$ gradients ( 3 to 10 or 7 to 11 ) followed by electrophoresis in a SDS-PAGE gel (12 or $10 \%$, respectively). In either case, two spots of $48 \mathrm{kDa}$ (designated p48.1 and p48.2) and two spots of $44 \mathrm{kDa}$ (designated p44.1 and p44.2) were detected (not shown). Spots were excised from the gels and subjected to tryptic digestion, and the mass of the tryptic peptides was determined by MALDI-TOF MS. Analysis of the spectra showed that all the spots had the same mass fingerprint (Fig. 6), strongly suggesting that p44 and p48 are variants of a single protein (protein $\mathrm{p} 48$ ). The masses of the tryptic peptides were used to perform database searches, which did not allow the identification of any protein homologous to protein $\mathrm{p} 48$.

Three different batches of the purified p48 and p44 were subjected to $\mathrm{N}$-terminal sequencing. In all three instances, no residue was found, indicating that both putative p48 variants were blocked at the N-terminus. Partial sequences of proteins p48 and p44 were deduced from the mass fragmentation spectra of peptides of the above-described four spots obtained after 2-D electrophoresis of fraction $\mathrm{P} 48$, either by collisioninduced fragmentation of selected peptides after mass fingerprint determination (matrix-assisted laser desorption-ionization time of flight tandem mass spectrometry [MALDI-TOF-TOF MS/MS]) or by fragmentation of peptides isolated after digestion of the protein and electrospray ionization of the peptides (ESI-Trap MS/MS). Table 1 lists all the peptide sequences deduced; those from MALDI-TOF-TOF MS/MS spectra are in bold, and the rest were deduced from ESI-Trap MS/MS spectra. It should be noted that spectra analysis does not allow for distinguishing leucine from isoleucine (L/I) and lysine from
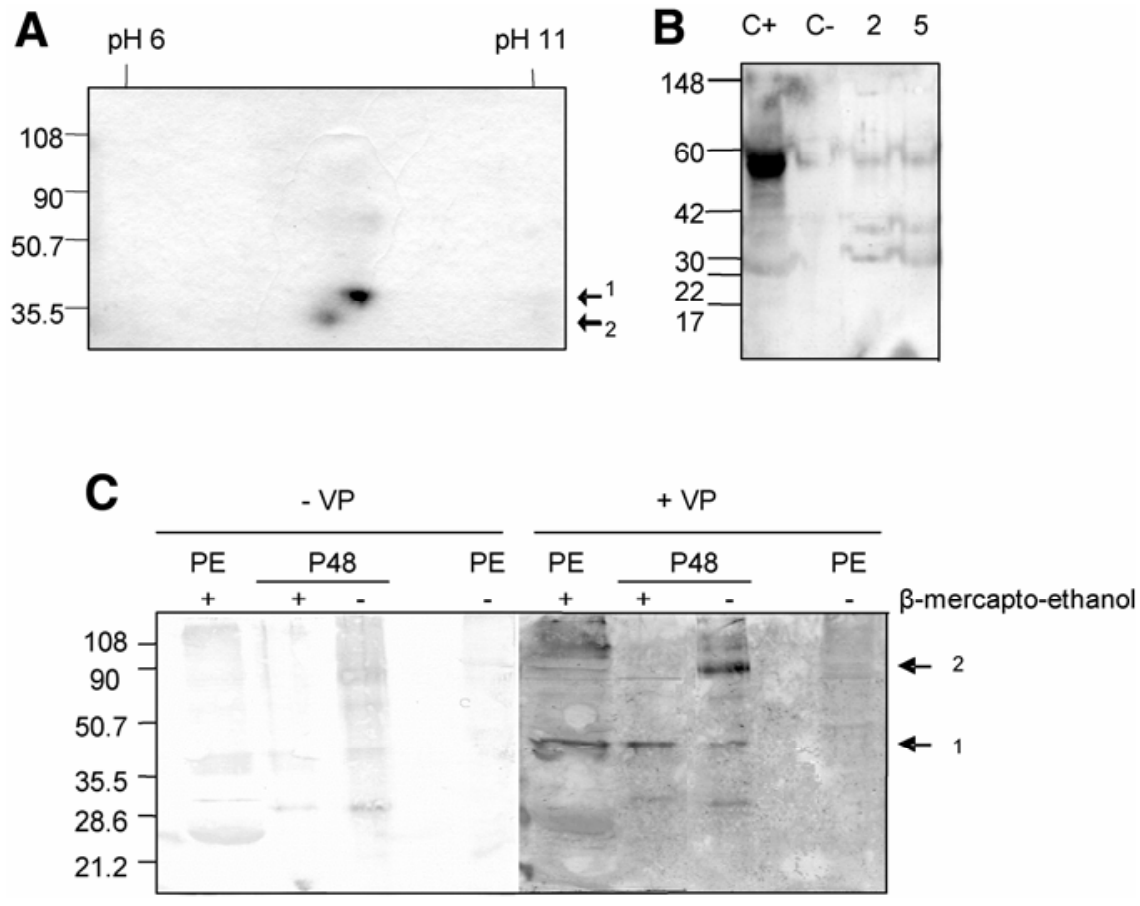

Fig. 5. Characterization of phloem exudate (PE) proteins p48 and p44. A, Two-dimensional electrophoresis of proteins in P48 fraction (Isoelectric focusing in a 6 to 11 linear $\mathrm{pH}$ gradient followed by sodium dodecyl sulfate-polyacrylamide gel electrophoresis [SDS-PAGE]).Gel was stained with Coomassie brilliant blue. The limits of the $\mathrm{pH}$ gradient are marked by $\mathrm{pH} 6$ and $\mathrm{pH} 11$. B, Immunodetection of complex N-linked glycans attached to proteins of fraction P48 ( 2 and $5 \mu \mathrm{g}$, lanes 2 and 5), bovine serum albumine $(3 \mu \mathrm{g}, \mathrm{C}-$ ), and horse radish peroxidase $(0.5 \mu \mathrm{g}, \mathrm{C}+)$ were separated by SDS-PAGE and were electroblotted to a polyvinylidene diflouride (PVDF) membrane. C, Analysis of intermolecular disulphide-bridge formation. Fraction P48 and PE samples were incubated with SDS-PAGE loading buffer with $(+)$ or without $(-) \beta$-mercapto-ethanol. Proteins were separated by SDS-PAGE and were electroblotted to PVDF membranes, and a gel overlay assay was done. Membranes were incubated in renaturation buffer alone (-VP) or with Cucumber mosaic virus (CMV) particles $(20 \mu \mathrm{g} / \mathrm{ml},+\mathrm{VP})$. Interactions were detected by incubating membranes with CMV antiserum. Arrows 1 and 2 indicate the position of CMV interacting proteins. Numbers at the left of the panel indicate molecular mass standards in $\mathrm{kDa}$. 
glutamine $(\mathrm{K} / \mathrm{Q})$, but lysine should be the C-terminal amino acid in all cases (Yates 2000). Furthermore, different sequences could be deduced, according to the mass of the smallest fragments obtained, from the fragmentation spectra of peptides 3,8 , and 9. Table 1 shows that peptides of equal mass (e.g., peptide 1), either from $\mathrm{p} 48$ or $\mathrm{p} 44$, have identical sequence, again indicating that p44 and p48 are variants of a single protein (p48). All possible peptide sequences were used to perform database searches. The most significant alignments of $\mathrm{p} 48$ peptides were with PP1 from Cucurbita maxima Dutch (accession number
AAC12676, Clark et al. 1997). Alignment of p48 peptides with the PP1 sequence showed that peptides YAVDDYNK (number 1 in Table 1), MMEALVEEEK (number 5), WIQIPDTK (number 2), NDKWIKIPDTK (number 8), ALVIEDAGKPK (number 3), and ECVDQWGSKK (number 4) showed homology within PP1, as shown in Figure 7. PP1 of Cucurbita maxima is a 96$\mathrm{kDa}$ protein with four repeats (Fig. 7) (Clark et al. 1997). Amino acid sequence identity between p48 peptides and PP1 varied between 38.6 and $50.7 \%$, and identity plus similarity varied between 65.7 and $72.4 \%$ for repeats R1 to R4 (Fig. 7). Thus, the

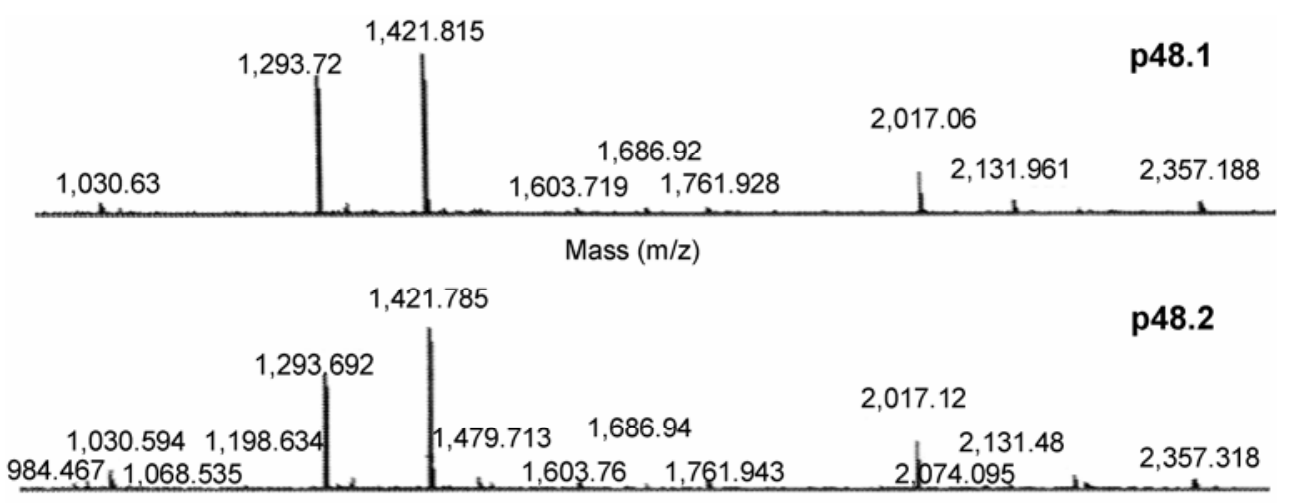

Mass $(\mathrm{m} / \mathrm{z})$
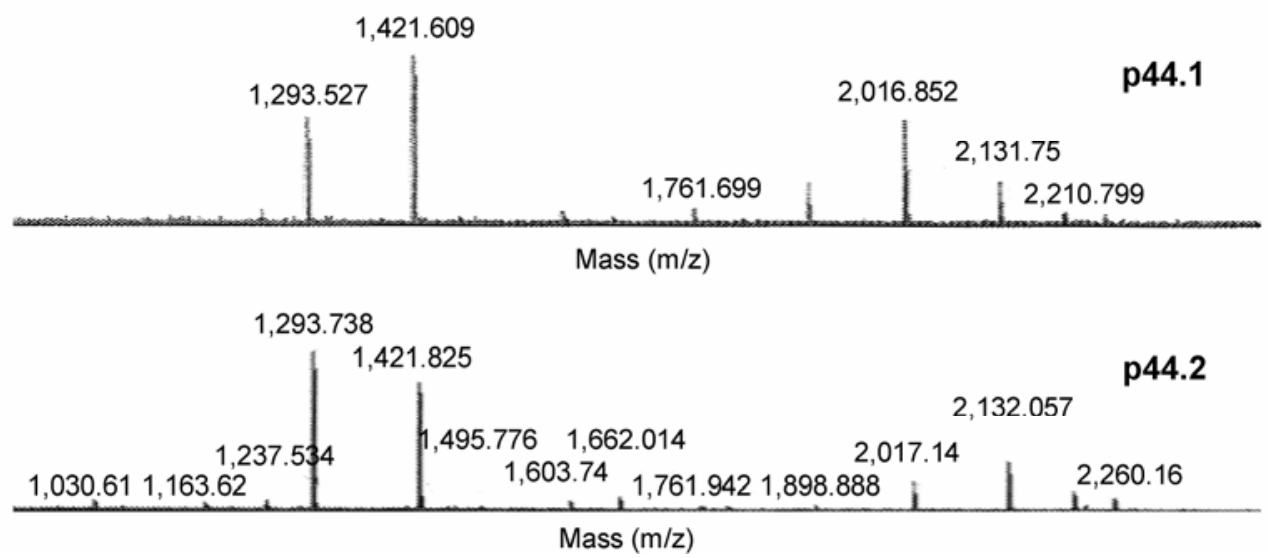

Fig. 6. Matrix-assisted laser desorption-ionization analysis of p48 and p44 tryptic peptides. Mass-spectrometric peptide maps obtained by tryptic digestion of the two spots of $48 \mathrm{kDa}$ (p48.1 and p48.2) and of the two spots of $44 \mathrm{kDa}$ (p44.1 and p44.2), obtained after two-dimensional electrophoresis of fraction P48 proteins in a nonlinear $\mathrm{pH} 7$ to 11 gradient followed by sodium dodecyl sulfate-polyacrylamide gel electrophoresis. The masses displayed at the spectra peaks are expressed in Da.

Table 1. Deduced peptide sequences from P48 fraction proteins ${ }^{\mathrm{a}}$

\begin{tabular}{|c|c|c|c|c|}
\hline Peptide number & Peptide mass (Da) & Peptide sequences & From p48 ${ }^{b}$ & From p44 \\
\hline 1 & 987.44 & YAVDDYNK & + & + \\
\hline 2 & $1,000.54$ & $\mathrm{~W}(\mathrm{~L} / \mathrm{I})(\mathrm{Q} / \mathrm{K})(\mathrm{L} / \mathrm{I}) \mathrm{PDTK}$ & + & N.A. \\
\hline \multirow[t]{4}{*}{3} & $1,140.58$ & PSV(L/I)EDAG(Q/K)PK & & \\
\hline & & SPV(L/I)EDAG(Q/K)PK & & \\
\hline & & (L/I)AV(L/I)EDAG(Q/K)PK & & \\
\hline & & $\mathrm{A}(\mathrm{L} / \mathrm{I}) \mathrm{V}(\mathrm{L} / \mathrm{I}) \mathrm{EDAG}(\mathrm{Q} / \mathrm{K}) \mathrm{PK}$ & N.A. & + \\
\hline 4 & $1,179.5$ & $\operatorname{ECVD}(\mathrm{Q} / \mathrm{K}) \mathrm{WGS}(\mathrm{Q} / \mathrm{K}) \mathrm{K}$ & + & + \\
\hline 5 & $1,224.58$ & (F/M)MEA(L/I)VEEEK & + & + \\
\hline 6 & $1,293.6$ & $(\mathbf{Q} / \mathrm{K}) \mathrm{NDFY}(\mathrm{L} / \mathrm{I})(\mathrm{L} / \mathrm{I}) \mathrm{RPK}$ & + & + \\
\hline 7 & $1,325.41$ & HHWFDN(L/I)DNK & + & + \\
\hline \multirow[t]{4}{*}{8} & $1,357.67$ & $\mathrm{DN}(\mathrm{Q} / \mathrm{K}) \mathrm{W}(\mathrm{L} / \mathrm{I})(\mathrm{Q} / \mathrm{K})(\mathrm{L} / \mathrm{I}) \mathrm{PDTK}$ & & \\
\hline & & $\mathrm{ND}(\mathrm{Q} / \mathrm{K}) \mathrm{W}(\mathrm{L} / \mathrm{I})(\mathrm{Q} / \mathrm{K})(\mathrm{L} / \mathrm{I}) \mathrm{PDTK}$ & & \\
\hline & & $(\mathrm{Q} / \mathrm{K}) \mathrm{T}(\mathrm{Q} / \mathrm{K}) \mathrm{W}(\mathrm{L} / \mathrm{I})(\mathrm{Q} / \mathrm{K})(\mathrm{L} / \mathrm{I}) \mathrm{PDTK}$ & & \\
\hline & & $\mathrm{T}(\mathrm{Q} / \mathrm{K})(\mathrm{Q} / \mathrm{K}) \mathrm{W}(\mathrm{L} / \mathrm{I})(\mathrm{Q} / \mathrm{K})(\mathrm{L} / \mathrm{I}) \mathrm{PDTK}$ & + & N.A. \\
\hline \multirow[t]{2}{*}{9} & $1,421.78$ & $(\mathbf{Q} / \mathbf{K}) \mathbf{N}(\mathbf{Q} / \mathbf{K}) \mathbf{D F Y}(\mathbf{L} / \mathbf{I})(\mathbf{L} / \mathbf{I}) \mathbf{R P K}$ & & \\
\hline & & $(\mathbf{Q} / \mathbf{K})(\mathbf{L} / \mathbf{I}) \mathbf{E D F Y}(\mathbf{L} / \mathbf{I})(\mathbf{L} / \mathbf{I}) \mathbf{R P K}$ & + & + \\
\hline
\end{tabular}

\footnotetext{
${ }^{a}$ Peptide sequences shown in bold face were determined by matrix-assisted laser desorption-ionization time of flight tandem mass spectrometry, the res were determined by electrospray ionization of the peptides.
}

b N.A. = not analyzed. 


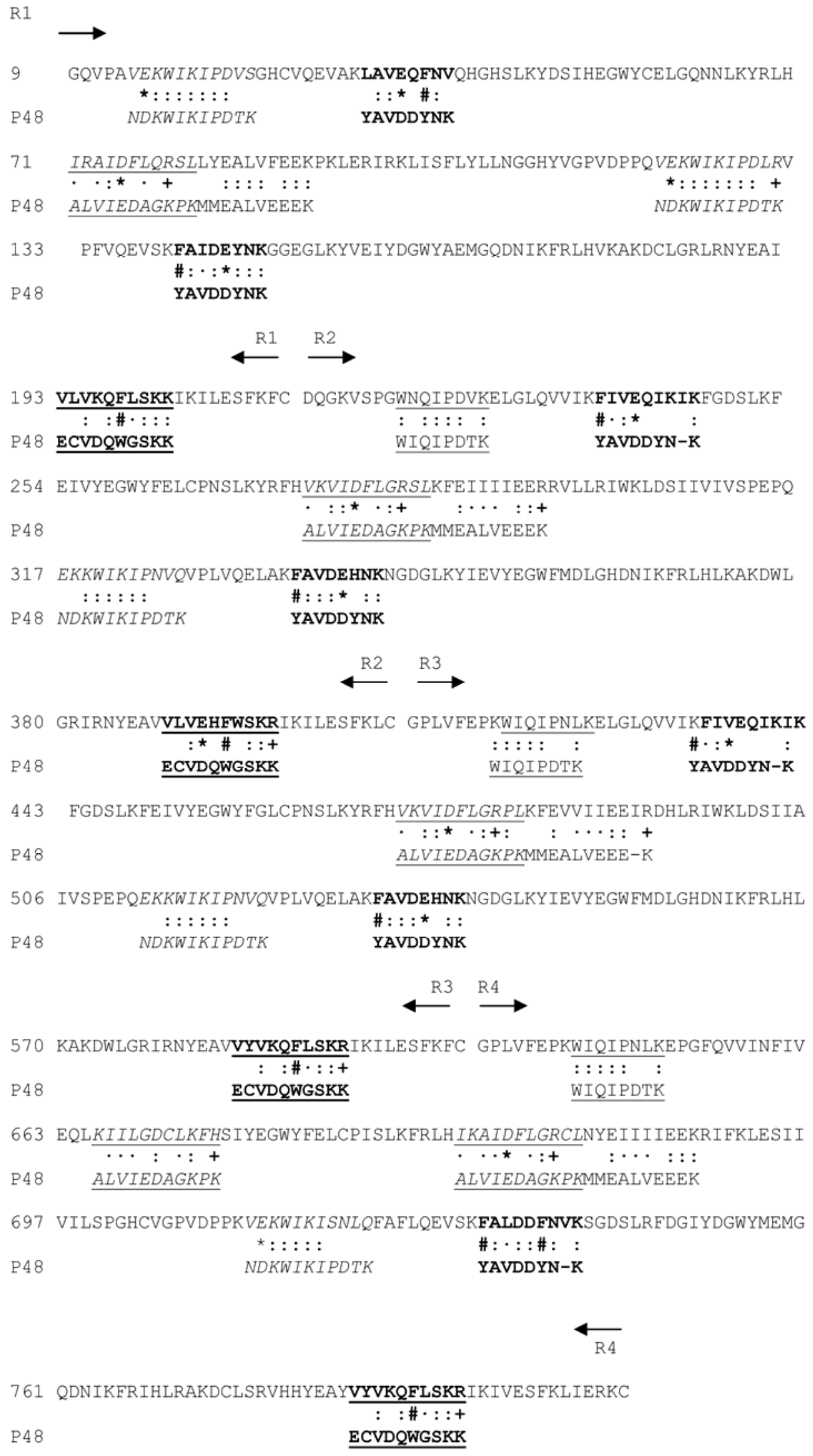

Fig. 7. Alignment of p48 tryptic peptides and the amino acid sequence of phloem protein 1 (PP1) from Cucurbita maxima. The upper line displays amino acid (aa) sequence of PP1, and the lower line shows p48 peptide sequences. Numbers at the left mark the aa position at PP1 sequence, and R1, R2, R3, and R4 stand for the four repeats of PP1 sequence. Sequence stretches homologous to peptides of p48 are shown, underlined for WIQIPDTK, in italics for NDKWIKIPDTK, in boldface for YAVDDYNK, in underlined boldface for ECVDQWGSKK, in underlined italics for ALVIEDAGKPK, and not highlighted for MMEALVEEEK. Properties of amino acids are indicated as follows: ':' indicate identical aa; '*' indicate D, E, acidic aa; '+' indicate R, K, H, basic aa; a single black dot (•) indicates G, A, V, L, I, aliphatic aa; '\#' indicate F, Y, W, aromatic aa; and '\&' indicates S, T, Q, N, polar aa. Gaps introduced for alignment are indicated by dashes (-). 
data indicate that $\mathrm{p} 48$ is a cucumber homolog of PP1 of Cucurbita maxima.

\section{DISCUSSION}

Present understanding of systemic movement of viruses on the phloem is limited, both regarding necessity of plant factors and the viral structures that move through sieve tubes (Oparka and Santa Cruz 2000; Scholthof 2005; Waigmann et al. 2004). We have approached the study of long-distance movement of CMV in cucumber plants. CMV moves long distance exclusively through phloem (Moreno et al. 2004), and there is indirect evidence derived from analysis of $\mathrm{CP}$ mutants and from electron microscopy that this occurs in the form of virions (Blackman et al. 1998; Kaplan et al. 1998; Schmitz and Rao 1998; Suzuki et al. 1991). However, results obtained with CP mutants could be due to a linkage of encapsidation and longdistance movement functions and microscope observations could reflect a mere accumulation of viral particles due to the infection process rather than the actual structure in the process of movement, and evidence for the presence of virion translocating in the phloem stream of plants is lacking. A handicap for the analysis of the translocating viral structures is the difficulty of obtaining phloem sap samples, because most plants respond to wounding in sieve tubes by instantly sealing sieve pore plates by callose deposition, cytoplasmic contents displacement, and P-proteins cross-linking (Oparka and Turgeon 1999; van Bel et al. 2002). In some plants, including species of the family Cucurbitaceae, the response to wounding is not instant, and reasonable amounts of PE can be obtained from sectioned stems and petioles that, by composition and properties, can be considered true samples of the phloem translocation stream (Thompson and Schulz 1999).

Electronmicroscopy and sedimentation analyses indicate that the main CMV structure moving through sieve tubes is the virion. If other structures also translocate, they were not detected by these analyses. Blackman and associates (1998) have proposed a model in which CMV would enter SE as a RNP structure formed by RNA, MP, and CP, and then, particle assembly would occur in membrane-bound structures in the SE, in which particles would accumulate until the membrane breaks and frees CMV virions that would move through the sieve tube. Our results showing the presence of nonaggregated virus particles in PE from CMV-infected plants do support this model; aggregates of virus particles sedimenting at the bottom of sucrose gradients are most probably formed during manipulation (compare treatments in Figure 1). As for the rod-shaped CGMMV (Simón-Buela and García-Arenal 1999), our data indicate that the icosahedric CMV particles move through cucumber sieve tubes and support the hypothesis that viruses move systemically in the form of viral particles, regardless of particle structure.

Systemic movement of a plant virus requires compatible interactions between host and virus factors (Scholthof 2005; Waigmann et al. 2004). In the case of CMV, interactions of both the MP (Kaplan et al. 1997; Takeshita et al. 2001) and the CP (Ryabov et al. 1999; Taliansky and García-Arenal 1995) with host factors are necessary for virus entry into the vascular system, but it is not known if interactions occur during, or are needed for, virus transport through sieve tubes. The possibility of CMV particles interacting with PE proteins was analyzed by gel overlay assays. This approach showed several PE proteins that interacted specifically with CMV particles (proteins p69, $\mathrm{p} 48$, and $\mathrm{p} 44$ ). These proteins did not interact with particles of TAV, a cucumovirus with particles very similar to those of CMV in structure and physiochemical properties but which does not infect cucumber plants systemically (Palukaitis and
García-Arenal 2003; Thompson and García-Arenal 1998) nor with those of CGMMV, a virus with rigid, rod-shaped particles that infects systemically cucumber plants (Simón-Buela and García-Arenal 1999). Interaction of CMV particles and PE proteins p69, p48, and p44 was stable at high salt concentrations, and interestingly, the range of salt concentrations at which these interactions were stronger (between 150 and $350 \mathrm{mM}$ ) included those found in PE of cucumber plants (170 to 180 $\mathrm{mM} \mathrm{NaCl}$; Owens et al. 2001), suggesting that similar interactions would be possible in vivo. Incubation of purified CMV particles with proteins p48 and p44 reconstituted the diminished accessibility of the encapsidated RNA to RNase A of CMV particles in the PE of infected cucumber plants, which suggests that interaction of p48 and p44 with CMV particles could occur in vivo. The high accessibility of encapsidated CMV RNA to ribonuclease cleavage (Habili and Francki 1974a) has been explained as due to pores in the pentameric units of the capsid (Smith et al. 2000), and it could be speculated that the interaction of CMV particles with PE proteins p48 and p44 would result in a diminished size of the pore.

The interaction between CMV particles and protein p48 of $\mathrm{PE}$ of cucumber plants is, to our knowledge, the first reported interaction between virus particles and phloem stream proteins. The plant pathogenic RNA Hop stunt viroid (HSVd) was shown to form RNP complexes in vitro with the PP2 from cucumber (Gómez and Pallás 2001; Owens et al. 2001). More recently, Gómez and Pallás (2004) have shown that HSVd interacts in vivo with PP2 in HSVd-infected cucumbers, and the RNP complexes move through intergeneric grafts. PP2 is a dimeric phloem lectin with plasmodesmata gating activity (Balachandran et al. 1997) known to move in the sieve tube stream (Golecki et al. 1999), suggesting a possible role of that interaction in the systemic movement of HSVd. These results are highly relevant as the first report of an in vivo interaction between host and pathogen factors during movement of a plant pathogen through sieve tubes and exemplify that an in vitro interaction may reflect an in vivo situation.

Proteins p48 and p44 are electrophoretic variants of a single protein, p48. As it has been suggested for PP2 (Wang et al. 1994), variants of $\mathrm{p} 48$ could be generated by post-translational modifications, although we found no evidence for glycosylation. Protein p48 is homologous to PP1 of Cucurbita maxima (pumpkin). Pumpkin PP1 is a $96-\mathrm{kDa}$ repetitive protein built of four homologous subunits spanning amino acids 9 to 212 (R1), 213 to 408 (R2), 409 to 604 (R3), and 605 to 809 (R4) (Clark et al. 1997). Accordingly, peptides of p48 homologous to pumpkin PP1 are found several times in the PP1 sequence at equivalent positions on the four repeats, with amino acid identities of 39 to $51 \%$ between the p48 peptides and PP1 (Fig. 7). High divergence of phloem proteins between the genera Cucurbita and Cucumis (Clark et al. 1997; Golecki et al. 1999 and Gómez and Pallás 2004) would explain that not every characterized peptide in $\mathrm{p} 48$ has a counterpart in pumpkin PP1. The same amino acid sequences were found for different $\mathrm{p} 48$ peptides (e.g., peptides 2 and 8 or 6 and 9 in Table 1) suggesting a repetitive structure for this protein, which, interestingly, forms disulfide bridge-stabilized dimers of a size similar to that of pumpkin PP1 (95 kDa). Protein p48 from cucumber also shares with PP1 from pumpkin a basic pI, the capacity to self-aggregate forming disulphide bridges, homology to cystatins, and the absence of complex N-linked oligosaccharides (Bostwick et al. 1992; Clark et al. 1997). A cucumber equivalent to protein PP1 from pumpkin has not been identified to date, in spite of exhaustive analysis that have allowed the identification of many proteins present in PE of cucumber plants (Walz et al. 2002, 2004). PP1 from pumpkin is synthesized in companion cells and transported into SE (Clark et al. 1997 and Oparka and 
Santa Cruz 2000). Along with the PP2 lectin, PP1 is a component of the P-protein filaments from the sieve tubes of cucurbits, and both proteins cross-link to plug sieve plates upon wounding (van Bel et al. 2002). Polymerized PP1 locates at the parietal layer of pumpkin SE (Bostwick et al. 1992; Clark et al. 1997; Oparka and Turgeon 1999), where CMV membrane-packed particles were observed (Blackman et al. 1998). Last, pumpkin PP1 has plasmodesmata-gating capacity (Balachandran et al. 1997) and is translocated with the phloem stream (Golecki et al. 1999; Oparka and Santa Cruz 2000). On the basis of shared properties and sequence conservation, similar properties could be hypothesized for $\mathrm{p} 48$.

Several possible roles in phloem transport can be speculated for the CMV particle-p48 interaction. The most obvious one, suggested by data on RNase accessibility, would be to modify CMV particle structure rendering the encapsidated RNA less accessible to ribonucleases activity in the sieve tubes. It is known that ribonucleases occur in the phloem translocation stream (Nelson and van Bel 1998; Oparka and Turgeon 1999), and phloem proteins have been shown to bind in vitro RNA molecules, as mRNA or siRNA, which are present in the phloem translocation stream, and phloem translocation of RNA in RNP structures seems to be general (Gómez et al. 2005; Ruíz-Medrano et al. 1999; Yoo et al. 2004). Also, interaction between CMV particles and p48 could result in "disguising" virions as endogenous components of cucumber phloem sap. Last, p48 could also have a role in helping MP-CP-RNA complexes to move from companion cells to SE, according to the model of Blackman and associates (1998), and once within the sieve tube, to direct the assembled particles to the appropriate sink tissues. Future work is necessary to test these hypotheses.

\section{MATERIALS AND METHODS}

\section{Viruses and plants.}

CMV Fny strain (Fny-CMV; Owen et al. 1990) was multiplied in tobacco plants (Nicotiana tabacum L. cv. Xanthi-nc.) inoculated at the four-leaf stage. Virus particles were purified according to Lot and associates (1972). Functional CP was obtained from CMV particles by $\mathrm{LiCl}$ disruption (Kaper 1969). Cucumber plants (Cucumis sativus L. cv. Toril) were inoculated at the cotyledons and at the first true leaf. Fully expanded leaves of Chenopodium quinoa were inoculated for local lesion assays. TAV V strain (V-TAV; Habili and Francki 1974b) was multiplied in tobacco plants inoculated at the four-leaf stage. Virus particles were purified according to Habili and Francki (1974b). CGMMV SH strain (CGMMV-SH; Ugaki et al. 1991) was multiplied in cucumber plants and was purified according to Fukuda and associates1981). All inoculations were made with a suspension of virus particles $(100 \mu \mathrm{g} / \mathrm{ml})$ in $0.1 \mathrm{M}$ sodium phosphate buffer, $\mathrm{pH}$ 7.0. Healthy and inoculated plants were kept in a greenhouse at 20 to $30^{\circ} \mathrm{C}$ with a 16-h light and 8-h dark cycle.

\section{Collection of PE from cucumber plants.}

Samples of PE were collected from the youngest petioles and internodes of CMV-inoculated or noninoculated cucumber plants transversally sectioned with a sterile scalpel. To minimize contamination with sap of parenchyma cells, the first drop of exudate was wiped off with tissue paper. Subsequent drops of exudate were immediately diluted in four volumes of PE buffer (PEB; $50 \mathrm{mM}$ sodium citrate, $\mathrm{pH} 7.0,1 \% \beta$-mercaptoethanol) (Simón-Buela and García-Arenal 1999). PE collection was always between 9 and 10 in the morning. Protein content in PE was quantified by Bio-Rad protein assay (Bio Rad, Hercules, CA, U.S.A.) and, on the average, was of $50 \mu \mathrm{g} / \mu \mathrm{l}$. The amount of PE protein used for the various assays is indicated at the respective sections. To remove proteins, PE in PEB was phenol- extracted and chloroform-reextracted. The last aqueous phase was considered nonprotein PE. To remove low-molecular weight compounds including ions, PE was dialyzed for $3 \mathrm{~h}$ against Milli-Q water (Millipore, Bedford, MA, U.S.A.), using a nitrocellulose filter with a pore diameter of $0.025 \mu \mathrm{m}$ (Millipore) floated over the water.

\section{Rate zonal centrifugation.}

Rate zonal centrifugation was done in continuous 5 to $25 \%$ sucrose gradients. PE total protein $(10 \mathrm{mg})$ from CMVinfected cucumber plants and $20 \mu \mathrm{g}$ of CMV particles, alone or mixed with $10 \mathrm{mg}$ of $\mathrm{PE}$ total protein from noninoculated cucumber plants, were centrifuged at $193,360 \times g$ for $90 \mathrm{~min}$ through a $10 \%$ sucrose cushion. Pellets were resuspended and loaded onto gradients, which were centrifuged at 317,000 $\times g$ for $35 \mathrm{~min}$. Fractions $(520 \mu \mathrm{l})$ were collected by hand from the top of the gradient. Each fraction $(15 \mu \mathrm{l})$ was dialyzed using a nitro-cellulose filter with a pore diameter of $0.025 \mu \mathrm{m}$ floated over Milli-Q water and was used to detect CMV CP by Western blot. Each fraction $(200 \mu \mathrm{l})$ was used for CMV RNA detection by Northern blot.

\section{Northern blot hybridization and Western immunoblot analyses.}

Samples of PE from cucumber plants (20 $\mu \mathrm{g}$ protein) and samples of gradient fractions from rate zonal centrifugation were phenol-extracted, chloroform-reextracted, ethanol-precipitated, and resuspended in sterile Milli-Q water. Nucleic acids were denatured and blotted onto nitro-cellulose membranes using a manifold dot-blot apparatus (Bio-Rad). CMV RNA was detected with a ${ }^{32} \mathrm{P}$-labeled RNA probe complementary to CMV CP (nucleotides 1,257 to 1,912 of Fny-CMV RNA 3, accession number D10538).

Samples of PE from cucumber plants and samples of gradient fractions from rate zonal centrifugation were separated in $12 \%$ SDS-PAGE gels and were electro-transferred to Protran nitrocellulose membranes (Schleicher \& Schuell, Dassel, Germany), as described (Sambrook and Russell 2001). Membranes were incubated with CMV antiserum at a 1:500 dilution in TNT (0.01 M Tris-HCl, $\mathrm{pH} 7.4,0.14 \mathrm{M} \mathrm{NaCl}, 0.1 \%$ Tween-20) with $5 \%$ nonfat milk and were then incubated with goat anti-rabbit alkaline phosphatase-conjugated antibodies (Sigma, St. Louis) (1:2,000 dilution). Antigen-primary antibody-secondary antibody complexes were visualized by the reaction of BCIP (5bromo-4-chloro-3-indolylphosphate; Sigma) and NBT (nitroblue tetrazolium; Sigma).

\section{Electron microscopy.}

Fractions from rate zonal centrifugation in which CMV RNA and CP were detected were centrifuged at $353,800 \times g$ for $30 \mathrm{~min}$. Pellets were resuspended in $0.1 \mathrm{M}$ sodium citrate, $\mathrm{pH} 7.0$, and were fixed in $2 \%$ glutaraldehyde in $10 \mu \mathrm{M}$ phosphate buffer, $\mathrm{pH}$ 7.0. Nickel grids coated with a carbon-formvar film (Electron Microscopy Sciences, Fort Washington, PA, U.S.A.) were floated over $15-\mu 1$ drops of sample. Unspecific binding sites were blocked by floating the grids over drops of $1 \%$ bovine serum albumin (BSA) diluted in PBS, and grids were incubated with CMV antiserum (1:1,000 dilution in 1\% BSA PBS) and then with goat anti-rabbit antibodies conjugated with $10 \mathrm{~nm}$ gold particles (Sigma) (dilution 1:10 in 1\% BSA in PBS) and were stained with $2 \%$ uranyl acetate . Grids were viewed under an electron microscope Jeol model Jem 10-10 (Jeol, Peabody, MA, U.S.A.) at a magnification of 120,000x.

\section{Gel overlay assays.}

PE from noninoculated cucumber plants was mixed with 0.1 $\mathrm{M}$ Tris- $\mathrm{HCl}, \mathrm{pH} 8.3,1 \% \beta$-mercapto-ethanol. PE total protein 
$(20 \mu \mathrm{g})$ or $5 \mu \mathrm{g}$ of fractionated P48 proteins (discussed below) were separated in $12 \%$ SDS-PAGE gels, and then, proteins were electroblotted onto Immobilon-P PVDF membranes (Millipore) in transfer buffer (Sambrook and Russell 2001) and membranes were washed with $0.03 \mathrm{M}$ Tris-HCl, $\mathrm{pH} 7.4$, $0.05 \%$ Tween-20. Blotted proteins were denatured, incubating the membranes twice in denaturation buffer, and were renatured by an overnight incubation at $4^{\circ} \mathrm{C}$ in renaturation buffer as described (Chen et al. 2000). For virus-binding assays, membranes were incubated with renaturation buffer with CMV, TAV, or CGMMV particles at $20 \mu \mathrm{g} / \mathrm{ml}$ for $2 \mathrm{~h}$ at room temperature. For CMV CP-binding assays, membranes were incubated similarly with renaturation buffer with CMV CP at $20 \mu \mathrm{g} / \mathrm{ml}$. Membranes incubated in renaturation buffer alone were used as negative controls. After virus or protein incubation, membranes were incubated with the appropriate antisera (1:500 dilution in $5 \%$ nonfat milk), and then with goat anti-rabbit alkaline phosphatase-conjugated antibodies (1:2,000 dilution in TNT with $5 \%$ nonfat milk). Protein-virus interactions or protein-protein interactions were visualized by the reaction of BCIP and NBT.

\section{Assay of sensitivity of virion RNA to RNase A.}

Purified CMV particles (200 ng) alone, mixed with PE from noninoculated cucumber plants $(150 \mu \mathrm{g}$ of total protein of PE in $\mathrm{PEB}, 150 \mu \mathrm{g}$ of total protein of dialyzed $\mathrm{PE}$, or the equivalent of $150 \mu \mathrm{g}$ of total protein [15 $\mu \mathrm{l}]$ of phenol-extracted PE), or mixed with $15 \mu \mathrm{g}$ protein from PEB-resuspended fractionated P48 were digested with RNase A. Similarly, $150 \mu \mathrm{g}$ of total protein of $\mathrm{PE}$ in $\mathrm{PEB}$ from CMV-infected cucumber plants was digested with RNase A. In all cases, samples were digested with RNase A at concentrations of $1.2 \times 10^{-1}, 2.5 \times 10^{-2}, 5 \times$ $10^{-3}, 1 \times 10^{-3}$, and $2 \times 10^{-4} \mu \mathrm{g} / \mu \mathrm{l}$ (Roche, Mannheim, Germany) in a final volume of $25 \mu$, and after incubation for $1 \mathrm{~h}$ at $37^{\circ} \mathrm{C}$, nondigested RNA was phenol-extracted and reverse transcribed, followed by polymerase chain reaction (PCR). Primers complementary and identical to nucleotides 1,902 to 1,925 and 1,256 to 1,274 , respectively, of CMV RNA 3 (nucleotide positions as in accession number D10538) were used. Untreated CMV particles (200 ng, equivalent to $40 \mathrm{ng}$ of RNA) in $25 \mu \mathrm{l}$ of PEB were used as a positive control. RT-PCR products were analyzed by electrophoresis in $1 \%$ agarose gels and were viewed after staining with ethidium bromide.

To assess the effect of PE on RNase A activity, $150 \mu \mathrm{g}$ of total protein of $\mathrm{PE}$ from noninoculated cucumber plants was mixed with RNase A, up to final concentrations of $5 \times 10^{-4}, 5 \times 10^{-6}$, and $5 \times 10^{-8} \mu \mathrm{g} / \mu \mathrm{l}$, was incubated with PE for 0,5 , or $30 \mathrm{~min}$ at $37^{\circ} \mathrm{C}$, and after incubation, $7.5 \mathrm{ng}$ of CGMMV RNA were added to the mix. After further incubation for $1 \mathrm{~h}$ at $37^{\circ} \mathrm{C}$, nondigested RNA was phenol-extracted and amplified by RT-PCR with primers LS1 and LS2 as described (Simón-Buela and García-Arenal 1999). To analyze ribonuclease activity at PE from noninoculated cucumber plants, CGMMV RNA (7.5 ng) was incubated with $150 \mu \mathrm{g}$ of total protein of PE from noninoculated cucumber plants for 0,5 , or $30 \mathrm{~min}$ at $37^{\circ} \mathrm{C}$, and nondigested RNA was phenol-extracted and amplified by RTPCR as described above.

\section{Purification of p48 and p44 proteins.}

Proteins of PE from cucumber plants were fractionated, adapting the protocol described by Owens and associates (2001). PE was mixed (1:3 vol/vol) with $50 \mathrm{mM} \mathrm{Na}_{2} \mathrm{HPO}_{4}$ $\mathrm{NaH}_{2} \mathrm{PO}_{4}$, pH 7.0, $300 \mathrm{mM} \mathrm{NaCl}, 1 \% \beta$-mercapto-ethanol, and $\mathrm{PE}$ proteins were fractionated by size exclusion chromatography, using a Sephacryl S-200 HR column (Amersham Pharmacia Biotech, Little Chalfont, U.K.). Fractions enriched in protein $\mathrm{p} 48$ were concentrated by centrifugation through Vivaspin 20 Concentrator filters with a pore diameter of 10
kDa (Vivascience, Hanover, Germany) and were resuspended in $1 \mathrm{mM}$ Tris-HCl, $\mathrm{pH} 8.2$ (F1 fraction). F1 fraction was applied to a Mono S HR 5/5 (Amersham Pharmacia Biotech) column equilibrated with $50 \mathrm{mM}$ HEPES (2-[4-(2-hydroxyethyl)-1piperazynil] ethanesulfonic acid), $\mathrm{pH} 7.2,0.5 \% \beta$-mercaptoethanol (buffer A) and with 50 mM HEPES, pH 7.2, $0.5 \% \beta$ mercapto-ethanol, $250 \mathrm{mM} \mathrm{NaCl}$ (buffer B). Proteins were eluted with a 0 to $100 \%$ linear gradient of buffer B. Fractions enriched in protein $\mathrm{p} 48$ were pooled in a single fraction $(\mathrm{P} 48$ fraction).

Aliquots of P48 fraction were desalted by centrifugation through Centricon filters with a pore diameter of $10 \mathrm{kDa}$ (Amicon Separation, Millipore), proteins were resuspended in Milli-Q water, were lyophilized and resuspended in the corresponding bidimensional rehydration buffer, and were applied to Immobiline DryStrip, $\mathrm{pH} 3$ to 10 or $\mathrm{pH} 6$ to 11 linear gradients. After IEF, strips were equilibrated in equilibration buffer (50 mM Tris- $\mathrm{HCl}, \mathrm{pH} 8.7,6 \mathrm{M}$ urea, 30\% glycerol, $2 \%$ SDS, $6.5 \mathrm{mM}$ DTT, $0.002 \%$ bromophenol blue) and were applied at the top of an $8 \%$ polyacrylamide SDS-PAGE gel. After electrophoresis, gels were stained with Coomassie brilliant blue (CBB) or proteins were electroblotted to PVDF membranes, and virus overlay assays were performed as described above.

\section{Characterization of protein $\mathbf{p} 48$.}

The presence of complex asparagine-linked glycans in $\mathrm{p} 48$ and p44 was analyzed in fraction P48 ( 2 or $5 \mu \mathrm{g}$ of protein) as described by García-Casado and associates (1996), using an antiserum against complex N-linked glycans of plant glycoproteins provided by M. J. Chrispeels (University of California, San Diego, U.S.A.).

To analyze the aggregation properties of p48 and p44 through disulphide-bridge formations, fraction $\mathrm{P} 48$ was dialyzed against Milli-Q water, using a Spectra/Por membrane with a pore diameter of $3.5 \mathrm{kDa}$ (Spectrum Laboratories, Breda, The Netherlands). Dialysis was made overnight at $4^{\circ} \mathrm{C}$ to allow partial renaturation of proteins and disulphide-bridge formation. Aliquots of the dialyzed fraction or $20 \mu \mathrm{g}$ of total protein of PE from noninoculated cucumber plants were mixed with SDS-PAGE loading buffer or with SDS-PAGE loading buffer without $\beta$-mercaptoethanol, and proteins were separated by SDS-PAGE (12\% polyacrylamide) and were electro-blotted to PVDF membranes to perform virus overlay assay or gels were stained with $\mathrm{CBB}$.

To determine the molecular masses of $\mathrm{p} 48$ and $\mathrm{p} 44$ proteins, aliquots of fraction $\mathrm{P} 48$ were desalted by centrifugation through filters with a pore diameter of $3.5 \mathrm{kDa}$. Proteins were resuspended in Milli-Q water, were lyophilized and resuspended in $30 \%$ acetonitrile, $0.3 \%$ trifluoroacetic acid, $10 \mathrm{mg} / \mathrm{ml}$ sinapic acid. This sample was analyzed by matrix-assisted laser desorption/ionization time-of-flight mass spectrometry (MALDI-TOF MS; Patterson and Aebersold 1995). MALDITOF MS was made in a Voyager DE-STR Biospectrometry Workstation (Applied Biosystems, Foster City, CA, U.S.A.).

To obtain mass fingerprints from $\mathrm{P} 48$ fraction proteins, aliquots of fraction $\mathrm{P} 48$ were desalted as described above. 2-D electrophoresis was carried out by IEF in a 3 to 10 nonlinear $\mathrm{pH}$ gradient followed by mass separation by SDS-PAGE (12\% polyacrylamide) or by IEF in a 7 to 11 nonlinear $\mathrm{pH}$ gradient followed by mass separation by SDS-PAGE (10\% polyacrylamide). After 2-D electrophoresis, gels were stained with CBB. Mass fingerprint profiles of spots of interest were obtained by excising the spots out of the gels, digesting the proteins with trypsin, and determining the peptide masses by MALDI-TOF MS (Courchesne and Patterson 1999). Determination of peptide masses was done in a 4700 Proteomics Analyzer (Applied Biosystems) or in an Ultraflex TOF/TOF (Bruker, Bremen, 
Germany). The database search using the peptide masses was performed with the Peptide Search program developed at the EMBL Protein \& Peptide Group. The searches were carried out at a mass accuracy of $\pm 0.3 \mathrm{Da}$, and the protein masses were restricted to the range between 40 and $60 \mathrm{kDa}$.

Determination of the N-terminal sequence of proteins p48 and p44 was by Edman degradation (Kamo and Tsugita 1999). Determination of internal sequences was by mass-spectrometric techniques. After mass determination of tryptic peptides by MALDI-TOF MS, the most abundant ones were submitted to collision induced fragmentation and the mass of the peptide fragments was analyzed by MALDI-TOF-TOF MS/MS. (Yates 2000). Peptide fragmentation and determination of fragment masses were made in a 4700 Proteomics Analyzer (Applied Biosystems). Alternatively, after tryptic digestion of the proteins, peptides were eluted from the gel and cleaned in an Ultimate nanoLC HPLC column (LC Packings; Dionex, Amsterdam, The Netherlands). Peptides were subjected to electrospray ionization, masses were analyzed by mass spectrometry, and selected peptides were isolated and trapped. Once isolated, peptides were subjected to fragmentation and the mass of the peptide fragments was analyzed by mass ESI-Trap MS/MS (Yates 2000). Peptide ionization, fragmentation, and fragment mass determination were made in an Esquire HCT (Bruker). With both techniques, peptide sequences were derived from the fragmentation spectra obtained. Database searches using the deduced peptide sequences were performed with BLAST from NCBI. Searches were made with all peptides individually and with all possible combinations of every two peptides. Searches were limited to Viridiplantae. Alignment of p48 sequences with proteins obtained after database searches was made with the SIM alignment tool for protein sequences, available at the Swiss Institute of Bioinformatics.

\section{ACKNOWLEDGMENTS}

Special thanks to I. Moreno Echanove for helping at the beginning of the work, to R. Sánchez-Monge for helping with protein purification, and to A. López Quirós for technical assistance. This work was supported in part by grant BIO99-1121-C02-02, CICYT, Spain. A. Requena was in receipt of a Formación de Personal Investigador (FPI) fellowship (PN 1999 11831919), Ministerio de Educación y Ciencia, Spain. Electron microscopy was done at the Centro de Microscopía Electrónica "Luis Brú", UCM, Madrid. 2-D electrophoresis with nonlinear 3 to $10 \mathrm{pH}$ gradient, MALDI-TOF MS, and MALDI-TOF-TOF MS/MS analysis were carried out at the Parque Científico de Madrid, UCM, Madrid. 2-D electrophoresis with nonlinear 7 to $11 \mathrm{pH}$ gradient, MALDI-TOF MS, and ESI-Trap MS/MS analysis were carried out at the Centro Nacional de Investigaciones Cardiológias, Ministerio de Sanidad y Consumo, Madrid.

\section{LITERATURE CITED}

Balachandran, S., Xiang, Y., Schobert, C., Thompson, G. A., and Lucas, W. J. 1997. Phloem sap proteins from Cucurbita maxima and Ricinus communis have the capacity to traffic cell to cell through plasmodesmata. Proc. Natl. Acad. Sci. U.S.A. 94:14150-14155.

Blackman, M. L., Boevink, P., Santa Cruz, S., Palukaitis, P., and Oparka, K. J. 1998. The movement protein of cucumber mosaic virus traffics into sieve elements in minor veins of Nicotiana benthamiana. Plant Cell 10:525-537.

Boevink, P., and Oparka, K. J. 2005. Virus-host interactions during movement processes. Plant Physiol. 138:1815-1821.

Bostwick, D. E., Dannenhoffer, J. M., Skaggs, M. I., Lister, R. M, Larkins, B. A., and Thompson, G. A. 1992. Pumpkin phloem lectin genes are specifically expressed in companion cells. Plant Cell 4:1539-1548.

Chen, M.-H., Sheng, J., Hind, G., Handa, A. K., and Citovsky, V. 2000. Interaction between the tobacco mosaic virus movement protein and host cell pectin methylesterases is required for viral cell-to-cell movement. EMBO (Eur. Mol. Biol. Organ.) J. 19:913-920.

Clark, A. M., Jacobsen, K. R., Bostwick, D. E., Dannenhoffer, J. M., Skaggs, M. I., and Thompson, G. A. 1997. Molecular characterization of a phloem-specific gene encoding the filament protein, Phloem Pro- tein 1 (PP1), from Cucurbita maxima. Plant J. 12:49-61.

Courchesne, P. L., and Patterson, S. D. 1999. Identification of proteins by matrix-assisted laser desorption/ionization mass spectrometry using peptide and fragment ion masses. Meth. Mol. Biol.112:487-511.

Ding, X. S., Shintaku, M. H., Carter, S. A., and Nelson, R. S. 1996. Invasion of minor veins of tobacco leaves inoculated with tobacco mosaic virus mutants defective in phloem-dependent movement. Proc. Natl. Acad. Sci. U.S.A. 93:11155-11160.

Fukuda, M., Meshi, T., Okada, Y., Otsuki, Y., and Takabe, I. 1981. Correlation between particle multiplicity and location on virion RNA of the assembly initiation site for viruses of the tobacco mosaic virus group. Proc. Natl. Acad. Sci. U.S.A. 78:4231-4235.

García-Casado, G., Sánchez-Monge, R., Chrispeels, M. J., Armentia, A., Salcedo, G., and Gómez, L. 1996. Role of complex asparagine-linked glycans in the allergenicity of plant glycoproteins. Glycobiology 6:471477.

Golecki, B., Schulz, A., and Thompson, G. A. 1999. Translocation of structural P proteins in the phloem. Plant Cell 11:127-140.

Gómez, G., and Pallás, V. 2001. Identification of an in vitro ribonucleoprotein complex between a viroid RNA and a phloem protein from cucumber plants. Mol. Plant-Microbe Interact. 14:910-913.

Gómez, G., and Pallás, V. 2004. A long-distance translocatable phloem protein from cucumber forms a ribonucleoprotein complex in vivo with Hop Stunt Viroid RNA. J. Virol. 78:10104-10110.

Gómez, G., Torres, H., and Pallás, V. 2005. Identification of translocatable RNA-binding phloem proteins from melon, potential components of the long-distance RNA transport system. Plant J. 41:107-116.

Habili, N., and Francki, R. I. B. 1974a. Comparative studies on tomato aspermy and cucumber mosaic viruses. I. Physical and chemical properties. Virology 57:392-401.

Habili, N., and Francki, R. I. B. 1974b. Comparative studies on tomato aspermy and cucumber mosaic viruses. II. Virus stability. Virology 160:29-36.

Kamo, M., and Tsugita, A. 1999. N-terminal amino acid sequencing of 2DE spots. Meth. Mol. Biol. 112:461-466.

Kaper, J. M. 1969. Reversible dissociation of cucumber mosaic virus (strain S). Virology 37:134-139.

Kaplan, I. B., Gal-On, A., and Palukaitis, P. 1997. Characterization of cucumber mosaic virus III. Localization of sequences in the movement protein controlling systemic infection in cucurbits. Virology 230:343349.

Kaplan, I. B., Zhang, L., and Palukaitis, P. 1998. Characterization of cucumber mosaic virus. V. Cell-to-cell movement requires capsid protein but not virions. Virology 246:221-231.

Lot, H., Marrou, J., Quiot, J. B., and Esvan, C. 1972. Contribution à l'étude du virus de la mosaïque du concombre (CMV). Méthode de purification rapide du virus. Annal. Phytopathol. 4:25-38.

Lucas, W. J. 2006. Plant viral movement proteins: Agents for cell-to-cell trafficking of viral genomes. Virology 344:169-184.

Moreno, I. M., Thompson, J. R., and García-Arenal, F. 2004. Analysis of the systemic colonization of cucumber plants by Cucumber green mottle mosaic virus. J. Gen. Virol. 85:749-759.

Nelson, R. S., and van Bel, A. J. E. 1998. The mystery of virus trafficking into, through and out of the vascular tissue. Prog. Bot. 59:476-533.

Oparka, K. J., and Santa Cruz, S. 2000. The great escape: Phloem transport and unloading of macromolecules. Ann. Rev. Plant Physiol. Plant Mol. Biol. 51:323-347.

Oparka, K. J., and Turgeon, R. 1999. Sieve elements and companion cells-Traffic control centers of the phloem. Plant Cell 11:739-750.

Owen, J., Shintaku, M., Aeschleman, P., Ben Tahar, S., and Palukaitis, P. 1990. Nucleotide sequence and evolutionary relationships of cucumber mosaic virus (CMV) strains: CMV RNA 3. J. Gen. Virol. 71:2243-2249

Owens, R. A., Blackburn, M., and Ding, B. 2001. Possible involvement of the phloem lectin in long-distance viroid movement. Mol. PlantMicrobe Interact.14:905-909.

Palukaitis, P., and García-Arenal, F. 2003. Cucumoviruses. Adv. Virus Res. 62:242-300.

Patterson, S. D., and Aebersold, R. 1995. Mass spectrometric approaches for the identification of gel-separated proteins. Electrophoresis 16:1791-1814.

Ruíz-Medrano, R., Xoconostlé-Cazarés, B., and Lucas, W. J. 1999. Phloem long-distance transport of CmNACP $m R N A$ : Implications for supracellular regulation in plants. Development 126:4405-4419.

Ruíz-Medrano, R., Xoconostlé-Cazarés, B., and Lucas, W. J. 2001. The phloem as a conduit for inter-organ communication. Curr. Opin. Plant Biol. 4:202-209.

Ryabov, E. V., Roberts, I. M., Palukaitis, P., and Taliansky, M. 1999. Hostspecific cell-to-cell and long-distance movements of cucumber mosaic virus are facilitated by the movement protein of groundnut rosette virus. Virology 260:98-108. 
Sambrook, J., and Russell, D. W. 2001. Molecular Cloning: A Laboratory Manual. Cold Spring Harbor Laboratory Press. Cold Spring Harbor, NY, U.S.A.

Santa Cruz, S. 1999. Perspective: Phloem transport of viruses and macromolecules-What goes in must come out. Trends Microbiol. 7:237-241.

Schmitz, I., and Rao, A. L. N. 1998. Deletions in the conserved amino-terminal basic arm of cucumber mosaic virus coat protein disrupt virion assembly but do not abolish infectivity and cell-to-cell movement. Virology 248:323-331.

Scholthof, H. B. 2005. Plant virus transport: Motions of functional equivalence. Trends Plant Sci. 10:376-382.

Simón-Buela, L., and García-Arenal, F. 1999. Virus particles of cucumber green mottle mosaic tobamovirus move systemically in the phloem of infected cucumber plants. Mol. Plant-Microbe Interact.12:112-118.

Sit, T. L., Haikal, P. R., Callaway, A. S., and Lommel, S. A. 2001. A single amino acid mutation in the Carnation ringspot virus capsid protein allows virion formation but prevents systemic infection. J. Virol. 19:9538-9542.

Smith, T. J., Chase, E., Schmidt, T., and Perry, K. 2000. The structure of cucumber mosaic virus and comparison to cowpea chlorotic mottle virus. J. Virol. 74:7578-7586.

Suzuki, M., Kuwata, S., Kataoka, J., Masuta, C., Nitta, N., and Takanami, Y. 1991. Functional analysis of deletion mutants of cucumber mosaic virus RNA 3 using an in vitro transcription system. Virology 183:106-113.

Takeshita, M., Suzuki, M., and Takanami, Y. 2001. Combination of amino acids in the 3 a protein and the coat protein of cucumber mosaic virus determines symptom expression and viral spread in bottle gourd. Arch. Virol. 146:697-711.

Taliansky, M. E., and García-Arenal, F. 1995. Role of cucumovirus capsid protein in long-distance movement within the infected plant. J. Virol. 69:916-922.

Thompson, G. A., and Schulz, A. 1999. Macromolecular trafficking in the phloem. Trends Plant Sci. 4:354-360.

Thompson, J. R., and García-Arenal, F. 1998. The bundle sheath-phloem interface of Cucumis sativus is a boundary for systemic infection by tomato aspermy virus. Mol. Plant-Microbe Interact. 11:109-114.

Ugaki, M., Tomiyama, M., Kakutani, T., Hidaka, S., Kiguchi, T., Nagata,
R., Sato, T., Motoyoshi, F., and Nishiguchi, M. 1991. The complete nucleotide sequence of cucumber green mottle mosaic virus (SH strain) genomic RNA. J. Gen. Virol. 72:1487-1495.

van Bel, A. J. E., Ehlers, K., and Knoblauch, M. 2002. Sieve elements caught in the act. Trends Plant Sci. 7:126-131.

Vaewhongs, A. A., and Lommel, S. A. 1995. Virion formation is required for the long-distance movement of red clover necrotic mosaic virus in movement protein transgenic plants. Virology 212:607-613.

Waigmann, E., Ueki, S., Trutnyeva, K., and Citovsky, V. 2004. The ins and outs of nondestructive cell-to-cell and systemic movement of plant viruses. Crit. Rev. Plant Sci. 23:195-250.

Walz, C., Juenger, M., Schad, M., and Kehr, J. 2002. Evidence for the presence and activity of a complete antioxidant defence system in mature sieve tubes. Plant J. 2:189-197.

Walz, C., Giavalisco, P., Schad, M., Juenger, M., Klose, J., and Kehr, J. 2004. Proteomics of curcurbit phloem exudate reveals a network of defence proteins. Phytochemistry 65:1795-1804.

Wang, M.-B., Boulter, D., and Gatehouse, J. A. 1994. Characterization and sequencing of cDNA clone encoding the phloem protein PP2 of Cucurbita pepo. Plant Mol. Biol. 24:159-170.

Xiong, Z., Kim H. K., Giesman-Cookmeyer, D., and Lommel, S. A. 1993. The roles of the red clover necrotic mosaic virus capsid and cell movement proteins in systemic infection. Virology 192:27-32.

Yates, J. R. 2000. Mass spectrometry. From genomics to proteomics. Trends Gen. 16:5-8.

Yoo, B.-C., Kragler, F., Varkony-Gasic, E., Haywood, V., Archer-Evans, S. Lee Y. M., Lough, T. J., and Lucas, W. J. 2004. A systemic small RNA signaling system in plants. Plant Cell 16:1979-2000.

\section{AUTHOR-RECOMMENDED INTERNET RESOURCES}

EMBL Protein and Peptide Group: www.mann.embl-heidelberg.de National Center for Biotechnology Information (NCBI) website: www.ncbi.nlm.nih.gov

Swiss Institute of Bioinformatics ExPASy (Expert Protein Analysis System) proteomics server: www.expasy.org 